\title{
Aesthetic Experiences, Ancient and Modern ${ }^{1}$ \\ Jonas Grethlein
}

\section{Aesthetic Experience Rediscovered}

The idea of aesthetic experience did not fare well in the second half of the $20^{\text {th }}$ century. Adorno and his disciples, clad in black, despised indulgence without reflection. A primarily non-intellectual reception was liable to lead into the snares of ideology. Under the influence of Adorno, ${ }^{2}$ a generation of intellectuals, at least in Europe, tried hard not to be carried away by catchy tunes and felt guilty for identifying with James Bond in the movie theater. Art's title to truth, a debt inherited from Hegel, led to a ban on the senses. Perhaps even more than Critical Theory, poststructuralism contributed to the disregard for aesthetic experience. The very idea of experience was shunned by a philosophy that replaced subjects with discourses and dissolved presence into traces: 'As to the concept of experience, it is very unfortunate here... it belongs to the history of metaphysics and we can only use it under erasure. ${ }^{3}$ Even Barthes' concept of jouissance, the voluptuous reading, refuses the reader an immersion in the fictive universe and instead aims at her masochistic disfiguration in plays of signification. In the Anglo-American tradition, Dewey's heritage dwindled soon. ${ }^{4}$ The notion of aesthetic experience became more and more confined in the course of the controversy between Beardsley and Dickie. ${ }^{5}$ In major analytical theories of art, it played no role. While aesthetic experience has no place in Goodman's semiological agenda, Danto denies it relevance to the definition of (modern) art. $^{6}$

Surely, there were dissenting voices: Launching an invective against the anemia of contemporary criticism, Susan Sontag fervently pleaded for an erotics of 
reading. ${ }^{7}$ In France, Mikel Dufrenne developed a phenomenological model of aesthetics while the German writer Karl Heinz Bohrer, tapping into the heritage of Romanticism and walking on Ernst Jünger's 'blutbetaute Wiesen', elaborated on suddenness and violence as salient traits of the aesthetic experience. ${ }^{8}$ That being said, such endeavors remained somehow marginal; the sway of the linguistic turn was too powerful. Only the last two decades have seen a reemergence of experience as a key concept of aesthetics. One of the most emphatic advocates of this shift is Hans Ulrich Gumbrecht. In his efforts to establish the idea of presence as an alternative to the paradigm of meaning, aesthetic experience figures prominently, as it is conceived 'as an oscillation (and sometimes as an interference) between 'presence effects' and 'meaning effects', 9 Trying to venture beyond the exclusive realm of aesthetic autonomy, Gumbrecht argues 'that we all feel how multiple modalities of aesthetic experience permeate our everyday worlds today (without becoming a part of or identical with the everyday)'. ${ }^{10}$

The thrust of Gumbrecht's mission is shared by the works of a couple of philosophers. ${ }^{11}$ Dieter Mersch, for example, sets out to redefine art as performance. ${ }^{12}$ He uses Benjamin's concept of aura as a frame for aesthetic experience which is not so much about significance as the simple fact of appearance and material presence. From this perspective, the emphasis of $20^{\text {th }}$-century art on abstraction and action is not a probing of the limits of art but a manifestation of its core. Appearance is also the central term of Martin Seel's aesthetics: ${ }^{13}$ art hinges on aesthetic experience which is directed towards appearances for the sake of appearance. While not denying the cognitive elements of aesthetic experience, Seel homes in on its sensual aspect.

Even in analytical philosophy with its much narrower concept of aesthetic experience, often confined to epistemic aspects, a new interest seems to have 
emerged. Richard Shusterman, for one, understands the decline of the concept of aesthetic experience as the consequence of deep conceptual confusion. ${ }^{14} \mathrm{~A}$ redemption of the idea of aesthetic experience seems not only possible, but, in the light of current developments, also highly desirable. While Shusterman finds inspiration in Dewey's broad notion of aesthetic experience, Noël Carroll makes a case for a deflationary, content-orientated, enumerative approach. For him, all that can be said about aesthetic experience is that it "involves design appreciation and/or the detection of aesthetic and expressive properties and/or attention to the ways in which the formal, aesthetic, and expressive properties of artwork are contrived ${ }^{15}$. As minimalist, if not to say truncated, as this definition is, it illustrates a re-awakened interest in experience also in Anglo-American aesthetics. Still without a lemma of its own in the four volumes of the Encyclopedia of Aesthetics published in 1998, aesthetic experience has an article for itself in the single-volumed Oxford Handbook of Aesthetics from 2003.

In pointing to 'a cultural environment that makes us fear we have lost touch with the materiality of things ${ }^{, 16}$, Gumbrecht provides a possible answer to the question as to why experience currently attracts so much attention in aesthetic theory. Besides being a powerful tool against the linguistic turn, the notion of experience also lends itself to securing the ground that seems to be endangered by virtual realities. Aesthetic experience is however not specifically the product of our current cultural environment. The anxiety of being disconnected from the 'real' world just draws our attention to the experiential dimension of our responses to art as well as of being in the world in general. Ancient aesthetics drive home that the immersive capacity of art is not a new phenomenon. A series of recent monographs demonstrate that the strong appeal of art looms large in ancient treatises. ${ }^{17}$ 
Plato is an unexpected case in point. He is usually considered, in the words of Nietzsche, 'the greatest enemy of the arts to rise from Europe so far' ${ }^{18}$, but his engagement with art is far more complex than this label has it. ${ }^{19}$ In Plato's Republic, Socrates not only pushes for banning art from the ideal state, but also speaks of it in terms of a former mistress that has not lost her allure yet $(607 b-608 b) .{ }^{20}$ Sontag's plea for an erotics of reading is here encapsulated in a metaphor. It is also important to note that Plato's critical stance is rooted in his sensitivity to the sway of art over its recipients. In the Republic, Socrates discusses the capacity of poetry to induce strong feelings in us (606a-b): 'And the best element in our nature, since it is not properly educated by reason or habit, relaxes its guard over the mournful part, for it contemplates sufferings of others and it is no shame to it to praise and pity another who, claiming to be a good man, abandons himself to excess in his grief.' Plato here has Socrates allude to a famous sentence in Gorgias' Encomium of Helen: (11.9 DK): 'Into those who hear it comes fearful fright and tearful pity and mournful longing, and at the successes and failures of others' affairs and persons the mind suffers, through the words, a suffering of its own.' However, Socrates condemns what Gorgias hails as evidence of brilliance: poetry exposes us to feelings that we otherwise try to repress. Nonetheless, Plato is highly aware of the strong physical and psychological reactions that poetry can elicit from us. Seen in the light of the current debate in aesthetics, Plato appears less as an enemy of the Muses than as a careful, if critical observer of dimensions of aesthetic experience of which Adorno, Derrida \& Co lost track.

In this essay, I wish to show that ancient authors provide fascinating material for the current discussion on aesthetic experience. Their emphasis on the immersive power of art can stimulate an aesthetic theory that tries to recover from the diet prescribed by poststructuralism, Critical Theory and the mainstream of analytical 
philosophy. Needless to say, the meditations of ancient authors do not fully map onto our current debate. This is the very chasm that allows ancient texts to cast light on present concerns. Here I will concentrate on reflections on narrative. ${ }^{21}$ It is striking that the philosophers mentioned above tend to focus on visual arts, be it the traditional tableau, installations or performances. Narrative is, if mentioned at all, rarely considered. While arguing for a radical extension in range of the objects of aesthetic experience, Gumbrecht shares the general disdain for narrative. In an article discussing the possibility of achieving presence in language, he notes 'that language can produce epiphanies in which the past is made present, ${ }^{22}$. However, 'this... evokes exceptional situations and achievements that have to be wrested, so to speak, from, and even against the grain of, the (for us) normal functioning of language.' Gumbrecht juxtaposes 'an analogical way of using language (presentifaction)' with 'a digital one (narrative or description)'. Accordingly, In 1926. Living at the Edge of Time offers a non-narrative account in order to make the past present. ${ }^{23}$ Given that the new interest in aesthetic experience is a move against the linguistic turn, the inclination to bypass narrative is not surprising. And yet, the testimony of ancient texts can alert us to the fact that narrative is not only a means of representation (as opposed to presence), but that it also has the capacity to trigger experiences in its recipients. $^{24}$

The power of words looms large in ancient theoreticians, ranging from Aristotle, who elaborates on pity and fear as our response to tragedy, to Longinus and his obsession with the sublime: the rhetorical phantasia 'not only persuades, but enslaves the listener' ([Longin.] Subl. 15.9). I will however forgo the easy harvest from theoretical treatises and instead consider meta-narrative, that is the reflections embedded in narratives themselves. The reason for this shift of focus is the additional 
complexity of meta-narrative that has reflection grind against narrative: being concomitant with the generation of aesthetic experience, its reflection becomes more dynamic. My first illustrating example comes from the beginning of ancient Greek literature, from the Odyssey (II); the second features in a text that stands near its end, the novel Ethiopica (III). The temporal gap and difference between prose and poetry notwithstanding, both Homer and Heliodorus piercingly reflect on the experiences narrative is able to trigger. But is it legitimate to relate ancient positions to our contemporary discussion? Are not art and aesthetics inventions of the Enlightenment period? How can therefore ancient texts shed light on them? A final section tackles this tricky issue and sketches an approach that tries to mediate between the caveats of historical semantics and the transhistorical claims of phenomenology (IV).

\section{The Tears of Odysseus}

The meta-narrative character of the Odyssey is striking: Numerous tales and songs mirror the epic in which they are embedded. ${ }^{25}$ The audiences in the Odyssey prefigure the recipients of the Odyssey. Sometimes the responses of the internal audience anticipate that of the external audience, sometimes they contrast; in any case, they cast light on each other. Particularly salient is the recital of three songs by the bard Demodocus at the court of Alcinous, the king of the Phaeacians. While the middle song is a burlesque account of infidelity among gods, the first and third songs deal with the Trojan War, more specifically with events in which Odysseus starred prominently: a quarrel between him and Agamemnon and the ruse of the wooden horse. Both stories touch Odysseus so much that he veils his head and cries. A simile underscores the intensity of his feelings (8.523-31, tr. Lattimore): 
As a woman weeps, when she falls on her dear husband, who's fallen in front of his city and people, warding off ruthless day from his city and children, and as she sees him gasping and dying, she throws her arms around him, and loudly wails, but those behind her strike her back and shoulders with their spears and lead her into bondage, to have hard work and hardship, and her cheeks waste away with the most piteous grief, so Odysseus let piteous tears fall from under his brows.

It is debated how much we should press this remarkable passage. ${ }^{26}$ The simile is closely related to the topic of Demodocus' song: the mourning of the female prisoner of war can be read as a sequel to the ruse that allowed the Greeks to enter the walls of Troy. ${ }^{27}$ The husband, who falls in front of the city defending his city and family, may even evoke more specifically Hector. ${ }^{28}$ In the view of many interpreters, the links between simile and Demodocus' song insinuate that Demodocus' song puts Odysseus into the shoes of his victims: like Achilles and Priam in Iliad 24, Odysseus senses the human condition that defines his enemies as well as him. Pointing out that Odysseus is only said to cry like the widow, others, including Schopenhauer, suggest more cautiously that Odysseus is affected by the contrast between his heroic stature in the Trojan War and his more recent ordeals. ${ }^{29}$ For the purposes of my argument, it is crucial that the response to a mere recital is compared with the reaction not only to an actual event, but to such a profound experience as the death of one's husband. Aesthetic experience is thereby aligned with intense real-life experiences. The 
comparison gains additional force through a double inversion: a male victor is juxtaposed with a female victim. This drives home the defenselessness of Odysseus against the emotions instilled in him by the recital.

Less obvious, but perhaps even more noteworthy is the alignment of Odysseus' listening with the woman's seeing. Together with the inversion of gender and role, the conflation of the senses highlights the intensity of reception experience, in particular as sight is generally considered to be more immediate than hearsay in ancient Greece. ${ }^{30}$ More specifically, it adumbrates the rhetorical category of enargeia, vividness, that would figure very prominently in critical treatises of the Imperial Age. The most salient aspect of enargeia, rooted in the word's etymology, is visual appeal. ${ }^{31}$ It is frequently defined as 'speech bringing what is being explained before the eyes'. ${ }^{32}$ In encapsulating the concept of enargeia, the simile of the crying widow, itself highly visual, bridges the gap between narrative and theory as well as between the Archaic and Imperial Ages.

Odysseus' tears thus indicate that, far from being predicated on the aloof stance of disinterestedness, the reception process is an intense experience that involves strong feelings and even a physical reaction. It would be however too easy to take Odysseus' reaction as a smooth mirror for the response of the Odyssey's audience. The Phaeacians indulge in the performance without signs of distress and thereby throw into relief the peculiar position of Odysseus. While Plato and Gorgias muse on recipients that feel the sufferings of others as their own, Odysseus witnesses an account of his own adventures. His position is therefore markedly different from that of the Homeric audience. It is equally questionable though to see in the Phaeacians a straight model. The life of the Phaeacians reflects aspects of a Golden Age just as Scheria is reminiscent of the Island of the Blessed. Alcinous and his 
people live a life of ease that is a far cry from the world of ordinary heroes and even more so with regard to the audience of Homer. Their detachment is sui generis. A critic therefore remarks: 'perhaps Odysseus's tears more accurately figure the norm for Homer's audience as well as for Aristotle's'. ${ }^{33}$ I think it is neither necessary nor helpful to choose one against the other. The diverging reactions of Phaeacians and Odysseus rather outline a spectrum in which the various responses of Homer's audience can range: somewhere from detached pleasure to strong involvement including tears. ${ }^{34}$ Besides illustrating the intensity that aesthetic experience can gain, Demodocus' recital reveals the wide range of possible responses and their dependence on the stance of the recipient.

Both poles of response to narrative come to the fore in other episodes of the Odyssey. In book 4, tales about the homecoming of heroes from Troy, including Odysseus, make first Telemachus and then also Menelaus, Helen and Peisistratus cry. Helen mixes into the wine a drug that, the narrator points out, would prevent somebody from crying even if he were to witness the slaying of the closest relatives (4.220-6). The drug allows the storytelling to continue without causing grief. As in the simile of the crying widow in book 8 , the response to song is compared to an extremely painful real life experience, but this time to highlight the detachment of the recipient. Ancient authors, namely Plutarch and Himerius, ${ }^{35}$ did not hesitate to read Helen's drug allegorically as a cipher for the distancing power of words. Much more could be said on Helen's drug, but for my argument it suffices to note that, if we follow the lead of the ancient readers mentioned, its effect crystallizes the distance that inheres in aesthetic experience, albeit to a varying extent. ${ }^{36}$

The other pole of aesthetic experience, that is immersion, is embodied by the Sirens. Their song is so enthralling that whoever hears it falls prey to its spell. The 
bones on the island of the Sirens attest the fate of wanderers who unheroically forgot about their nostos. The metapoetic significance of the episode is obvious: 'enchanting by the melody of their singing' (12.44) and claiming to 'know everything' (12.189), the Sirens are strongly reminiscent of the Muses into whose fountain the epic poet taps. The Sirens' song has been described as 'a ghastly imitation of epic'. ${ }^{37}$ More specifically it has been seen as reminiscent of the Iliad while also evoking lyric poetry. ${ }^{38}$ For my interpretation, it is crucial that the song of the Sirens is uncannily beautiful: it provokes an aesthetic experience that, being more intense than real life experience, has the capacity to replace it. Art threatens to extinguish life. Only the chain binding Odysseus to the mast allows him to keep the distance that prevents full immersion.

It is emblematic that Adorno and Horkheimer read the Siren episode as a parable of class struggle. Odysseus as landlord is opposed to the rowing comrades who figure as the workers. The Siren episode intimates that the bourgeois indulgence in art hinges on the exploitation of labour: 'In this way the enjoyment of art and manual work diverge as the primeval world is left behind. The epic already contains the correct theory. Between the cultural heritage and enforced work here is a precise correlation, and both are founded on the inescapable compulsion toward the social control of nature ${ }^{39}$ The interpretation of the Odyssey in the Dialektik der Aufklärung is a standout highlight in the long history of Homeric exegesis, and yet in its onesidedness it illustrates the shortcomings of Critical Aesthetics. A philosophy that sees art only in its relation to ideology has to miss the profound reflection on the abyss of aesthetic experience inherent in the Siren episode.

It would be easy to give further passages from the Odyssey that can be read as meditations on aesthetic experience, but the examples adduced already show the 
complexity of its reflection. The Odyssey highlights the experiential character of responses to narrative that has not only been downplayed by adherents of poststructuralism and Critical Theory, but is also ignored in more recent works rediscovering the idea of aesthetic experience: narrative is more than a means of representation; the strong reactions it can provoke drive home its capacity to create presence. While underscoring the immersive appeal of narrative, the Odyssey does not fail to note the distance constitutive of aesthetic experience. The interaction between reflection on narrative and narrative itself adds to the complexity of these reflections. The response of the recipients of the Odyssey does not simply map onto the reactions of the listeners in the Odyssey. The two audiences are rather hinged together in a way that lets them grind against each other. Sometimes the external audience smoothly continues the reaction of the internal audience; sometimes it rubs against it. The simultaneous generation of, and reflection on, aesthetic experience gives meta-narrative an additional twist and makes it more intriguing than theoretical treatises.

III. Reflection and Immersion in Heliodorus

Turning from Homer to Heliodorus, we move to a very different cultural setting. While the Odyssey is the product of a long oral tradition that is likely to have been recited first mainly at public festivals, the Ethiopica, the romance of Charicleia and Theagenes, were written sometime in the $3^{\text {rd }}$ or $4^{\text {th }}$ century CE and belong to the flourishing literary culture of the Second Sophistic. These differences notwithstanding, Heliodorus' novel, besides capitalizing on the Odyssey as intertext, continues its reflections on aesthetic experience. ${ }^{40}$ Nowadays studied only by a small 
group of experts, the Ethiopica, after being translated into the vernacular languages, was a key text for both early modern poetics and the rise of the modern novel. Scaliger, for example, one of the most prominent scholars of the $16^{\text {th }}$ century, wrote: 'I believe that the epic poet should read this book very carefully and regard it as the very best model. ${ }^{41}$ In addition to the poet Spenser, Sidney and the first writers of French romance, the author of Arcadia, Cervantes, was influenced by the narrative art of Heliodorus. ${ }^{42}$ The Ethiopica, 'the ancient world's summa, a self-consciously encyclopaedic synthesis of a thousand years of accumulated pagan plot techniques, ${ }^{43}$, brilliantly entwines multiple plot strands and nests up to four levels of narrative. Its treatment of narrative and narrated time is breathtaking: it takes the reader five books, half of the novel, to grasp the prehistory and fully understand the initial scene. Even readers that have feasted on such labyrinthian movies such as $\underline{\text { Memento }}$ will be splendidly entertained by Heliodorus.

Similarly to the Odyssey, inset tales endow the Ethiopica with a strong metanarrative level. The longest of these narrations fills most of the novel's first half: the sly Egyptian Calasiris tells an Athenian named Cnemon how Charicleia and Theagenes fell in love and came to Egypt. Cnemon's responses that from time to time punctuate the embedded narrative reveal how fully he is enwrapped in its plot. His immersion has been interpreted along different lines. In a seminal paper that explores the meta-narrative significance of the Ethiopica, Jack Winkler argues that 'it is Knemon's special failing to respond to literature as if it were life... He cannot sustain the critical distance which drama and novels require as representations of reality. ${ }^{44}$ Drawing on Barthes' distinction between the 'readerly' and 'writerly' modes of reception, Winkler condemns Cnemon as 'lector non scrupulosus' who illustrates how the Ethiopica ought not to be read. Readers are not supposed to identify with 
characters and immerse themselves in the world of the action, but ought to analyze soberly the play with signification in all its ramifications. Other scholars though disagree with Winkler and read Cnemon's immersion as a positive model for the reader of the Ethiopica: 'Knemon presents an exact fit, cognitively and affectively, with the reader. ${ }^{45}$ This take on Cnemon is better attuned to the sensitivities of ancient readers for whom a strong involvement of recipients signals the high quality of a text. The prominence of enargeia in rhetorical and critical treatises illustrates the high esteem enjoyed by immersive narrative particularly in the Second Sophistic. That being said, I would like to discuss an exemplary passage to show that either interpretation is too simple. Cnemon's responses highlight not only the spell narrative can cast over its audience, but illustrate the intricate relation between immersion and reflection and thereby let us see a central tenet of poststructuralism in a new light.

Calasiris, the paternal friend of Charicleia and Theagenes, offers his narration of their adventures in exchange for Cnemon's promise that the couple will join them very soon. Narrating how Charicleia and Theagenes met in Delphi, Calasiris lavishly elaborates on their dashing appearance at a procession - and is interrupted by Cnemon $(3.4):^{46}$

'It's them!' exclaimed Cnemon. 'It's Charicleia and Theagenes!' 'Where are they? In the gods' name, show me!' implored Calasiris, supposing that Cnemon could actually see them. 'Father, I believed I saw them, although they are not here. So vividly did your description show them as I know them from my own experience.' 'I doubt', said Calasiris, 'that you have seen them as Greece and the sun gazed upon them that day, universally admired, 
universally acclaimed. Men lost their hearts to Charicleia, and women theirs to Theagenes. To know the love of one of them, people thought, must be like immortality, although the locals admired more the young man, and the Thessalians the maid, each being more struck by what they were seeing for the first time. For an unfamiliar sight is generally more impressive than one well known to us.' 'Such a sweet deception, such a sweet belief, how you furnished me with wings, when I thought you could see and show the beloved. But it seems that you have been deceiving me all along, because at the beginning of my story you gave me your word that they were on their way and would appear any second - and, what is more, you demanded payment in the form of their history. Now it is evening and night, and still you cannot show them.'

One could not wish for a better illustration of enargeia: Calasiris' account lets Cnemon visualize the procession. Cnemon even uses the adjective of the technical term enargeia to praise the vividness of the presentation. That being said, the passage underscores that aesthetic experience hinges on reflection as well as immersion. As a critic notes, 'it is not Knemon, but Kalasiris who is deluded'. ${ }^{47}$ Aesthetic illusion is thus thrown into relief by real delusion. While Calasiris expects that Charicleia and Theagenes are actually coming around the corner, Cnemon, as absorbed as he is, is facing Calasiris and aware that he is following a narration. A vivid account may move us to visualize a scene, but it is distinct from the mistaken belief that something absent is actually present. The juxtaposition with actual delusion underlines that aesthetic illusion is a 'willing suspension of disbelief'.

Calasiris's additional comment can be read as a qualification of the power of imagination. He obviously doubts that Cnemon has seen Charicleia and Theagenes in 
the splendor with which they were endowed during the procession. His words though permit a reading along different lines: If we refer 'you have seen' to what Cnemon 'believes' that he 'saw' during the narration, the capacity of his imagination to reproduce the scene mentally is challenged. What is primarily a trope to highlight the extraordinariness of the scene implies a comment on the limits of aesthetic illusion: no matter how strong the spell cast by a tale is, the recipient will fail to envision the scene fully as it happened.

The neat juxtaposition of aesthetic illusion with delusion is subtly blurred. Heliodorus semantically mitigates the contrast: Cnemon 'believed (ôiêthên) I saw them, although they are not here' and Calasiris invokes his 'sweet belief (oiêseôs)' The deployment of the same words blends together not only aesthetic illusion and delusion, but also narrative and reality: Calasiris reminds Cnemon of his promise and asks him to 'show' (deiknye) him Charicleia and Theagenes, using the verb two more times in the same sense (deiknynai) ${ }^{48}$ Strikingly, Cnemon applies a compound form of the same verb to narrative: 'So vividly did your description show (hypedeixen) them as I know them from my own experience.' While the use of the same stem undercuts the dichotomy of narrative deixis and actual showing, the prefix hypooften adding a quantum of obliqueness, insinuates a distinction that cannot be erased. Calasiris invokes 'sweet deception' (̂ tês hêdeias apatês) and accuses Cnemon of deceiving him (exapatan). He feels cheated because Cnemon has failed to produce the couple, as he had promised to do in exchange for his tale. That being said, the adjective 'sweet', which qualifies 'deception', suggests understanding it also aesthetically. As a famous Gorgias fragment illustrates (B 23 DK), apatê has a longstanding history as a terminus for aesthetic experience: Tragedy is named as a genre that provides its audience with 'a deception in which the one who succeeds in 
deceiving, rather than the one who fails to do so, has right on his side, and in which the deceived is wiser than the undeceived.' In the Imperial era, another highly reflective text, the younger Philostratus' Imagines, features the very phrase 'sweet deception' (hêdeia apatê, proem 4) applied to the power of a picture. ${ }^{49}$ The use of vocabulary apt for aesthetic experience implicitly aligns Calasiris' delusion with Cnemon's absorption.

As these observations show, the scene does not simply illustrate enargeia as the capacity of narrative to conjure up a scenery before the inner eye of the audience; its reflection is considerably more nuanced. The response of Calasiris to Cnemon's interruption offsets aesthetic experience against delusion. While reverberations subtly challenge a clear-cut dichotomy between narration and deception, Heliodorus is far from propagating a mimeticism that eradicates the boundary between fiction and reality. On the contrary, the scintillating play that Heliodorus sets up requires the distinction.

The passage gains a further twist if we relate the intervention of Cnemon to the response of Heliodorus' reader. Paradoxically, Cnemon's exclamation that expresses his absorption goes against the immersion of the readers as it draws their attention to the mediation of the story: far from directly witnessing the procession, they follow Calasiris' account in a novel by Heliodorus. Perhaps, the relation between immersion and reflection is even more intricate. The reader is alerted to the mediation of the embedded tale, but the focus on the embedding story, that is Calasiris' conversation with Cnemon, as frame of the embedded story can heighten the immersion in the primary narrative. Our response to the plot is of course always accompanied by a residual awareness of the fact that we are only reading a novel, but envisaging the primary narrative as frame of a secondary narrative may contribute to 
making the frame of the novel drop out of focus. This visual parallel may help to clarify the point: when we concentrate on a picture in a picture or a film in a film, the awareness that what we see in the first place is only a picture or film fades without completely vanishing.

Another intervention of Cnemon illustrates that reflective elements may intensify the reader's absorption: When Calasiris, narrating a footrace in which Theagenes competed, describes the scene and lingers on the anxiety with which the audience waited for the outcome, Cnemon interrupts him again (4.3.4): 'It is not surprising,' said Cnemon, 'that those who were there watching were in agony. Even now I fear for Theagenes and beg you to make haste and tell me whether he was proclaimed victor.' When Cnemon begs Calasiris to hurry with his recital, the effect on the reader, who is as eager as Cnemon to learn the outcome of the race, is the opposite - the interruption retards the story. While the intervention alerts the reader to narratorial mediation, the retardation heightens suspense and thereby strengthens the immersive appeal of the narrative.

Besides highlighting the experiential dimension of responses to narrative and in addition to illustrating the intricate interplay between the implicit reflection on narrative and narrative itself that we also observed in the Odyssey, the Ethiopica allow us to make a new point. Reflection and self-reference are at the core of poststructuralist readings. As Winkler's interpretation of the Ethiopica illustrates, poststructuralists tend to oppose reflection and immersion: the 'readerly' reception of Cnemon contrasts with the superior 'writerly' mode of Winkler's ideal reader who keeps distance and penetrates Heliodorus' meta-narrative wit. At first sight, this juxtaposition may seem plausible, as meta-narrative highlights narratorial mediation and thereby focuses the reader's attention on the fact that she is not directly 
witnessing the events. However, Heliodorus' intricate entanglement of reflection and immersion, both at the level of the action and in its interplay with the position of the Ethiopica's reader, underscores that they are not mutually exclusive. The narrative maze of the Ethiopica tightly interlaces reflection and immersion. Winkler is as right in his emphasis on the novel's strong meta-narrative dimension as is another scholar who claims 'that virtually everything is geared to one end: intensity of experience for the reader'. ${ }^{50}$ The holy grail of poststructuralism, reflection, has the capacity to foster the readerly stance that poststructuralists abhor, that is, immersion. ${ }^{51}$

My main point concerns narrative, the experiential dimension of which is neglected in theory, but this observation on reflection also pertains to the visual arts. In a Hegelian mold, Danto claims that, due to an increasing degree of reflectivity, aesthetic experience plays no role for modern art: '....aesthetical considerations, which climaxed in the eighteenth century, have no essential application to what I shall speak of as 'art after the end of art' - i.e. art produced from the late 1960s on. ${ }^{52}$ Danto's thesis has not remained unchallenged. Martin Seel, for one, points out that 'Danto is one-sidedly concerned with the difference between artworks and other things and not so much with artworks and other signs. ${ }^{, 53}$ Duchamp's ready-mades and Warhol's brillo boxes only succeed in exhibiting the paradoxes of artistic appearance through appearance; the beholder has to sense and experience them in order to grasp the challenge posed to the idea of art. The reflection inherent in modern art thus hinges on its experience.

Let me complement this point by giving an example that combines narrative with visual art, namely theatre: Katie Mitchell's Cologne production of Reise durch die Nacht, a stage adaptation of Friederike Mayröcker's story that was nominated for the Berliner Festspiele 2013 , is emblematic of the trend of using multiple media in 
contemporary theater. The stage shows a train with several compartments and, above it, a screen on which the images of several cameras on the stage are projected. While the actors can be seen through this projection as well as directly, another actress, also visible in one of the train compartments, reads the inner monologue of the main protagonist, a middle-aged woman, who travels from Paris to Vienna with her husband. The production is thus highly reflective; the cameras as well as the separation of the visual from the auditive alert the spectator to the mediation: the staging does not aim at illusion but highlights its character as representation. Nonetheless, the acting on stage, the flux of images and the text read out add up to a highly poetic scene. Contrasting with the intimacy of the inner monologue, the medial dissection makes the fragmented state of memories tangible. While marking the means of mediation, the production cannot fail to pull the audience into the world of the play. As this example illustrates, reflection and experience are by no means mutually exclusive on the stage.

IV. Between Phenomenology and Historical Semantics

My argument encapsulates a conspicuous tension: I suggest reading ancient texts in order to stimulate the current debate on aesthetic theory. This means making use of specific historical semantics for conclusions that are not specifically historical. Why, to ask more pointedly, should ancient reflections on responses to narrative be still valid today? The inverse question is even more trenchant: is it legitimate to confront ancient texts with the category of aesthetic experience? The word 'aesthetics' has Greek roots, but it is generally agreed that the discipline was founded by Alexander Gottlieb Baumgarten. It is even controversial whether or not one is 
entitled to speak of art in antiquity. In an influential article, Paul Oskar Kristeller argued that the modern system of the arts was 'invented' around $1750 \mathrm{CE}$. The notion of arts in antiquity is therefore a flagrant anachronism: 'We have to admit the conclusion, distasteful to many historians of aesthetics but grudgingly admitted by most of them, that ancient writers and thinkers, though confronted with excellent works of art and quite susceptible to their charm, were neither able nor eager to detach the aesthetic quality of these works of art from their intellectual, moral, religious and practical function or content... ${ }^{54}$

Kristeller's thesis, while often referenced, has been subjected to severe criticism. Classicists have been able to show that his assertions about antiquity are badly documented and ignore much evidence. ${ }^{55}$ That being said, it is important to heed the different setting of art in antiquity. Visual art may be the most glaring case: it has been argued that pictures and statues of gods were more than representations and made the divinity somehow present. ${ }^{56}$ They were worshipped, washed and dressed as if they were the divinities themselves: 'The representation is not just in the image, the represented is the image. ${ }^{57}$ The difference between such a ritual mode of viewing and our 'museal' appreciation of images is too obvious to be argued. A similar point can be made for theater: we may watch the same tragedies as Athenians in the $5^{\text {th }}$ century $\mathrm{BCE}$; and yet our theaters, whether they are thought to serve the purposes of entertainment or to accumulate cultural capital, provide a setting that does not match the religious and political frame of the Great Dionysia. To take up one of my sample texts: Being alone in a room and reading silently the Odyssey is worlds apart from listening to a bard recite the same text in a crowd at a Panhellenic festival.

At the same time, Jeremy Tanner has shown that ancient and modern notions of art are not incomparable. ${ }^{58}$ Particularly the Hellenistic age increasingly created 
such places as sculpture gardens and picture galleries that favored mainly aesthetic modes of viewing. ${ }^{59}$ Despite noting similarities between art in ancient and modern thought, Tanner remains sensitive to the remaining gap which he tries to explain in sociological and politological terms. I would like to follow here a different path and invoke phenomenology as a means of pinpointing the common ground that makes it possible and fruitful to envisage aesthetic experience today in light of ancient texts without ignoring the crucial differences. ${ }^{60}$ I do not argue that historical semantics are built on top of an anthropologically constant ground. In any act of perception both are closely entwined with each other. ${ }^{61}$ And yet, it is possible to focus on the phenomenological aspect of perception without claiming that it constitutes a separate stage. I find this phenomenological aspect in the notion of 'as-if'. Different as they are, ancient and modern aesthetic experiences are aligned by the structure of 'as-if'. Besides varying from medium to medium, this basic 'as-if' receives a specific shape from its historical and cultural context. This essay is not the place to develop an aesthetic theory and set it off from other approaches, ${ }^{62}$ but in order to buttress my argument I will briefly sketch the 'as-if' of our response to narrative and picture.

For narrative, I draw on Husserl's exploration of our consciousness of time. ${ }^{63}$ Wondering how various phases can constitute temporal continuum, Husserl explores the notion of a sound: it starts, continues and fades, but nonetheless it appears to us as a single unit. The key to Husserl's approach is the idea of retention. Impressions make way for new impressions, but instead of simply vanishing, past impressions are retained in the modified form of retention which is present with the actual impression that is itself about to be transformed into a retention including the retention of its own retentions etc. ${ }^{64}$ Perception is thus not a mere point, but contains an 'Abschattungsreihe' in which previous 'nows' have sedimented. Distinct from this 
continuously moving chain of retentions is memory or secondary retention. Memory is not the presence of 'nows' that have just passed, but the representation of something that is not present anymore in the continuum of perception. In contrast to the past moment to which our attention is directed, this representation recalls also the chain of retentions of that passed moment. ${ }^{65}$

The goal of explaining the notion of continuum lets Husserl focus on retention, primary and secondary, but he also introduces the concept of protention and expectation, though much more fleetingly. Protentions correspond to primary retentions just as expectations mirror memory. Our impressions have not only a chain of retentions retaining the impressions that have just passed, but also come with protentions, intentions of the consciousness that are directed to what is to come. ${ }^{66}$ Likewise, besides recalling past impressions including their array of pro- and retentions, the consciousness can also produce images of the future. ${ }^{67}$ Husserl introduces the notion of protention only when he discusses 'Erwartungsintentionen' in memory ${ }^{68}$ and elaborates on expectation only by comparing it with memory, ${ }^{69}$ and yet for a systematic analysis of the temporal dynamic of consciousness the orientation to the future is as important as the openness to the past. Heidegger, replacing Husserl's focus on perception with his emphasis on 'Sorge', would even privilege the future dimension in Sein und Zeit.

Husserl's explanation of the temporal structure of our perception of the everyday world also applies to our reception of narrative. When we follow a story, the temporal structure of our consciousness refers to its plot. We have both retentions and memories of what has happened in the story and anticipate what is going to happen. Note that the temporal dynamics of the reader's consciousness duplicate the temporal dynamics of the characters' consciousness. The two, however, do not have to be, and 
most often are not, identical; it is rather the tension between them that defines the character of a story. ${ }^{70}$ Central to my argument is that, when we follow a story, our retentions and protentions are cast in the frame of 'as-if'. While focusing on what has happened and what is about to happen in the plot, we remain aware of attending only to a story. ${ }^{71}$ As much as we may immerse ourselves in the world of a narrative, there is a residual awareness of our real environment, sustained for example by our holding a book in the hands or our facing a four-dimensional screen. This awareness, reflected, as we have seen, in the Ethiopica, is proven by the fact that we, say, do not jump up from our seat to flee the approaching murderer. At the same time, the shiver we feel attests the focus of our protentions on the development of the plot.

The 'as-if' of narrative is thus temporal: narrative lets us direct primary and secondary pro- and retentions to a sequence which we know to be not our everyday world. As I have already pointed out, narratives can have a wide range of settings which have an impact on the process of reception. The differences between reading and listening, between individual and communal experience are considerable. It also matters whether we deem the story to be fictional or factual. In all cases, however, the temporal dynamics of our consciousness is directed at the sequence of the narrative and is bracketed. The various socio-cultural forms of reception are all predicated on the common fundament of an experience in the realm of 'as-if'.

A similar case can be made, mutatis mutandis, for pictures. Richard Neer has recently reconsidered Vernant's thesis that in ancient Greece the concept of image did not emerge until the Classical period. ${ }^{72}$ At least some of Vernant's articles seem to imply not only the observation that Archaic Greeks lacked a concept of image - they

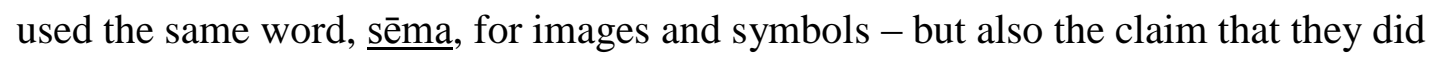
not experience pictorial representation as different from such symbolic operators as 
bird omens. While acknowledging the insights of Vernant's discussion, Neer refutes this thesis by arguing that the evidence still visible to us, that is our own experience of Archaic images, tells us more about the experience of Archaic Greeks than how they verbally referred to their images: "phenomenology grounds philology. ${ }^{, 73}$ The decipherment of Linear B, the writing system used by Greeks during the Bronze Age, is a compelling illustration of this thesis: ${ }^{74}$ Puzzling over the remaining texts, mostly lists, the architect Michael Ventris assigned sound-values to the signs. His decipherment, however, was only confirmed when archaeologists unearthed a text that juxtaposed signs with pictures: a clay tablet from Pylos that features pictures of tripods and flagons, followed by a mark signifying the number and Linear B characters that, in Ventris' system, read as 'ti-ri-po-de', that is tripods: 'The comprehensibility of the figural representation had analytical priority over the comprehensibility of the writing system, such that the figural representations verified the decipherment of the script (as opposed to the other way around). We assume the figural representations to be comprehensible prior to the script; indeed, the comprehensibility of the figures grounds that of the script. ${ }^{75}$ Of course, an anecdote from the $20^{\text {th }}$ century CE cannot, strictly speaking, prove perceptual habits in the $7^{\text {th }}$ century BCE. And yet, it is hard to believe that Archaic Greeks, having the Pylian tablet in front of them, would have failed to recognize the tripods just as they were unable to read the Linear B text.

The notion of 'seeing-in', coined by Wollheim, can show that our seeing of pictures is phenomenologically grounded in an 'as-if'. Wollheim argues that pictures require a special mode of seeing, a concept which he spells out in a critique of Gombrich's illusion theory. ${ }^{76}$ Gombrich adduces the well-known drawing that can be seen either as a duck or as a rabbit as evidence for his thesis that we see either the 
canvas or the object represented, but never both simultaneously. The example of the duck-rabbit, however, made famous by its discussion in Wittgenstein's

Philosophische Untersuchungen, has no bearing on the dichotomy of canvas and object of representation. The choice between rabbit and duck is mutually exclusive indeed: one can see only either, but it is a choice between two different objects of representation, not between representing object and represented object. In his 'twofold thesis', Wollheim argues that it is not only possible, but necessary to attend simultaneously to the object of a representation and its material features. ${ }^{77}$ Seeing pictures is based on 'a special perceptual capacity, which presupposes, but is something over and above, straightforward perception. ${ }^{78}$ Wollheim labels this special mode of perception 'seeing-in': When we see an object in a picture, we are aware of the canvas as well as the represented object. Initially, Wollheim introduced seeing represented object and seeing representing object as two experiences. Later, he treated them as 'two aspects of a single experience that I have'. 'D9 'Discerning something in the marked surface', on the one hand, is the 'recognitional aspect'; 'our awareness of the marked surface itself', on the other, is the 'configurational aspect'. ${ }^{80}$

Most of the detailed arguments with which Wollheim put forward his concept were successfully challenged, ${ }^{81}$ and yet the points raised did not chip away from the overall plausibility of 'seeing-in'. The perhaps most incisive critique of the concept of 'seeing-in' is that it has little explanatory power: Wollheim does not clarify, indeed he deems it impossible to clarify, how we actually see an object in a picture. ${ }^{82}$ What exactly is it that allows us to see more than lines and dots? This lacuna may undermine Wollheim's claim to furnish a full-blown theory of pictorial representation; it does not, though, reduce the value of 'seeing-in' for my argument. 'Twofoldedness' grasps the 'as-if' in seeing pictures that is pivotal to it. On the one 
hand, we see the object represented; on the other, the attention to the representing object alerts us to the fact that the represented object we see is not 'real'. The 'as-if', temporal for narrative, is spatial in the case of pictorial representation. We see an object in front of us and simultaneously see that it is not there. Our vision of the represented object, just as the chain of pro- and retentions in the reception of narrative, is bracketed by 'as-if'.

I have already mentioned the ritual mode of viewing in antiquity that deviates significantly from the disinterested appreciation of art so popular in modern aesthetics. It would be easy to list yet other concepts of gaze. Arguing 'that the 'aesthetic attitude' is a specific historical product of the religious crisis of the Enlightenment and the rise of Western science, and that it has no applicability to civilizations which have not internalized the Enlightenment as we have', ${ }^{83}$ Gell discusses for example Indian pictures: ${ }^{84}$ in Hinduism images are the object not so much of aesthetic response as of worship. As Gell describes it, there is a reciprocal relation between the beholder and the deity represented. The eyes of the worshipper, Indian philosophers believe, reach out to the picture and touch its object. The eyes of the deity inversely bestow 'darshan' on the beholder. 'Darshan' is a 'particular type of blessing conveyed through the eyes', ${ }^{85}$ it emanates from pictures as well as from real persons.

The salient differences notwithstanding, all these modes of viewing pictures involve 'seeing-in'. There is no doubt that the Hindu receiving 'darshan' from the exchange of gazes with a representation of Shiva engages in a different activity from the European who looks at the same picture in an art exhibition. But while interacting with the deity in the picture, the beholder has to 'see' the divinity 'in' the picture. She has to recognize that she is not looking at a mere piece of wood, but at a pictorial 
representation. The wood does not feature a random selection of color dots, including two symmetrical dark circles with white circles around them; it represents the eyes of a divinity from which the blessing emanates. The reverential gaze is predicated on the same process of 'seeing-in' as that of a European art connoisseur comparing the eyes of Shiva with the calculating eyes of a merchant portrayed by Jan van Eyck.

This sketch of the 'as-if' in narrative and picture, cursory as it is, ${ }^{86}$ lets us see the modern concept of aesthetic experience in a new light. The idea of disinterested reception - if it can be maintained at all $-{ }^{87}$ is not as peculiar as anthropologists like Gell assume. It is distinct in reinforcing the phenomenological 'as-if', which, however, it shares with other cultural modes of perception. In addition to bracketing the perceptual experience, the modern aesthetic attitude further extracts the object of its attention from pragmatic constraints. Take the case of pictures: In an essay on 'homo 27ictor', Hans Jonas elaborates on the distance that separates pictorial representation from real things: 'It (i.e. the similarity of pictorial representation) can represent the dangerous without being dangerous, the harmful without harming, the desired without satiating. What is represented in the picture is extricated from the causal traffic of things and converted into a non-dynamic form of existence... ${ }^{, 88}$ In the modern conception of aesthetic experience, not only the represented object, but the picture itself is removed from the causal traffic of things - this is manifest in the institution of the museum. As Gadamer points out, the museum is one of the places that cater to the 'aesthetic distinction': in depriving pictures and other artistic works of a specific context and occasional character, the museum invites a disinterested stance. ${ }^{89}$ It is important however to see that the idea of disinterested perception and its spatial realization in the museum, while being specific to the modern period, builds on the 'as-if' of aesthetic experience that is phenomenologically grounded. Inversely, 
other cultures entwine art with religious and political aspects, and yet the response to it, while different from the detached attitude of the connoisseur, is predicated on an experiential 'as-if'.

The phenomenological aspect of aesthetic experience makes it possible to engage ancient reflections in a dialogue with the current debate in art theory. Aesthetic experience, ancient testimonies suggest, is not only epistemic, as analytical philosophers tend to argue. Even narrative, a medium that is still associated mainly with the linguistic turn, has the capacity to provoke strong psychological and physical reactions. Counter to the assumptions of poststructuralism and analytical philosophy, ancient meta-narrative drives home that experience and reflection do not have to be mutually exclusive. While heeding specific historical semantics, the dialogue I propose goes beyond a historicist investigation. The emphasis on the significance of ancient positions for current debates also renders it different from studies in reception and 'Nachleben'. At the same time, my approach does not imply a return to the Classicist fallacy that celebrates antiquity as the ideal model. It is rather premised on the friction between phenomenology and historical semantics which makes it worthwhile to see in ancient texts more than sources for the study of antiquity.

Heidelberg University

\footnotetext{
${ }^{1}$ I wish to thank Daniel Boyarin, Stephen Halliwell and Michael Squire as well as Rita Felski and an anonymous reader for their comments and suggestions. The work on this essay was funded by the European Research Council (ERC Grant Agreement n. 312321, AncNar).

${ }^{2}$ Theodor W. Adorno, Ästhetische Theorie (Frankfurt: Suhrkamp, 1970).

${ }^{3}$ Jacques Derrida, De la grammatologie (Paris: Éditions de Minuit, 1967), 89.

${ }^{4}$ John Dewey, Art as Experience (New York: Penguin, 1934).

${ }^{5}$ Cf Monroe C. Beardsley, Aesthetics. Problems in the Philosophy of Criticism (New York: Harcourt,
} 
Brace \& World, 1958); Monroe C. Beardsley, The Aesthetic Point of View (Ithaca and New York:

Cornell Univ. Press, 1982); George Dickie, Art and the Aesthetic. An Institutional Analysis (Ithaca and London: Cornell Univ. Press, 1974).

${ }^{6}$ Arthur Coleman Danto, The Philosophical Disenfranchisement of Art (New York: Columbia Univ. Press, 1986); Nelson Goodman, Languages of Art: An Approach to a Theory of Symbols (Indianapolis: Bobbs-Merrill, 1968).

${ }^{7}$ Susan Sontag, Against Interpretation and Other Essays (New York: Picador, 1961).

${ }^{8}$ Mikel Dufrenne, Phénomenologie de l'expérience esthétique. I-III (Paris: Presses universitaires de France, 1953); Mikel Dufrenne, Esthétique et philosophie. II (Paris: Klincksieck, 1976); Karl Heinz Bohrer, Suddenness: On the Moment of Aesthetic Appearance (New York: Columbia Univ. Press, 1994).

${ }^{9}$ Hans Ulrich Gumbrecht, Production of Presence. What Meaning Cannot Convey (Stanford: Stanford Univ. Press, 2004), 2.

${ }^{10}$ Hans Ulrich Gumbrecht, “Aesthetic Experience in Everyday Worlds: Reclaiming an Unredeemed Utopian Motif,” New Literary History 37 (2006a), 299-318: 301.

${ }^{11}$ For a recent collection of different takes on aesthetic experience, see Stefan Deines, Jasper Liptow and Martin Seel, ed., Kunst und Erfahrung. Beiträge zu einer philosophischen Kontroverse (Berlin: Suhrkamp, 2013).

${ }^{12}$ Dieter Mersch, Ereignis und Aura. Untersuchungen zu einer Ästhetik des Performativen (Frankfurt: Suhrkamp, 2002a). Dieter Mersch, Was sich zeigt. Materialität, Präsenz, Ereignis (Munich: Fink, 2002b) fleshes out a theory of presence of which hermeneutics, semiotics and deconstruction, despite their differences, are equally oblivious.

${ }^{13}$ Martin Seel, Aesthetics of Appearing (Stanford: Stanford Univ. Press, 2004).

${ }^{14}$ Richard Shusterman, “The End of Aesthetic Experience,” The Journal of Aesthetics and Art Criticism 55 (1997), 29-41.

${ }^{15}$ Noel Carroll, "Art and the Domain of the Aesthetic," British Journal of Aesthetics 42 (2000), 191208: 207. See also Noel Carroll, “Aesthetic Experience Revisited,” British Journal of Aesthetics 42 (2002), 145-68

${ }^{16}$ Gumbrecht, "Aesthetic Experience in Everyday Worlds,” 306.

${ }^{17}$ Jim I. Porter, The Origins of Aesthetic Thought in Ancient Greece: Matter, Sensation, and 
Experience (Cambridge: Cambridge Univ. Press, 2010); Stephen Halliwell, Between Ecstasy and Truth: Interpretations of Greek Poetics from Homer to Longinus (Oxford: Oxford Univ. Press, 2011); Anastasia-Erasmia Peponi, Frontiers of Pleasure: Models of Aesthetic Response in Archaic and Classical Greek Thought (New York and Oxford: Oxford Univ. Press, 2012). On ancient criticism, see also Stephen Halliwell, The Aesthetics of Mimesis. Ancient Texts and Modern Problems (Princeton: Princeton Univ. Press, 2002); Andrew Ford, The Origins of Criticism. Literary Culture and Poetic Theory in Classical Greece (Princeton: Princeton Univ. Press, 2002); Richard L. Hunter, Critical Moments in Classical Literature. Studies in the Ancient View of Literature and its Uses (Cambridge: Cambridge Univ. Press, 2009).

${ }^{18}$ Friedrich Nietzsche, On the Genealogy of Morals (New York: Vintage Books, 1969 [1887]), 3.25.

${ }^{19}$ See, for example, the nuanced readings of Halliwell, The Aesthetics of Mimesis, 37-147; 155-207.

${ }^{20}$ Cf. Halliwell, Between Ecstasy and Truth, 190-207.

${ }^{21}$ I understand narrative broadly as representation in a temporal medium of a temporal sequence featuring human or human-like characters. This definition embraces theatre and film as well as stories in the traditional sense.

${ }^{22}$ Hans Ulrich Gumbrecht, "Presence Achieved in Language (With Special Attention Given to the Presence of the Past)," $\underline{H \& T} 45$ (2006b), 317-27: 325.

${ }^{23}$ Hans Ulrich Gumbrecht, In 1926: Living at the Edge of Time (Cambridge, MA: Harvard Univ. Press, 1997).

${ }^{24}$ It is also striking that narratologists and literary scholars have little to say on the experiential aspect of narrative. Monika Fludernik, Towards a 'Natural' Narratology (London: Routledge, 1996) is an exception in that she makes 'experientiality' the cornerstone of her natural narratology, but her concept of experience remains vague. It is, for example, not clear if she refers to experiences of characters or readers. Another narratologist who is sensitive to the issue of experience is Marie-Laure Ryan, Narrative as Virtual Reality: Immersion and Interactivity in Literature and Electronic Media (Baltimore: Johns Hopkins Univ. Press, 2001), who takes her cue from studies in virtual reality. Rita Felski, Uses of Literature (Malden and Oxford: Blackwell, 2008), 51-76 discusses 'enchantment' as one of four modes of our engagement with literature. From the perspective of psychology, see Richard J. Gerrig, Experiencing Narrative Worlds. On the Psychological Activities of Reading (New Haven: 
Yale Univ. Press, 1993) who considers the state of 'being transported'.

${ }^{25}$ See, for example, Walter Marg, Homer über die Dichtung (Münster: Aschendorff, 1957), 7-20;

Charles Segal, Singers, Heroes, and Gods in the Odyssey (Ithaca: Cornell Univ. Press, 1994), 85-109;

Halliwell, Between Ecstasy and Truth, 36-92; and, for more literature, Peponi, Frontiers of Pleasure,

33 n. 1.

${ }^{26}$ For bibliography, see Halliwell, Between Ecstasy and Truth, 88 n. 104.

${ }^{27}$ Cf. Yoav Rinon, Homer and the Dual Model of the Tragic (Ann Arbor: Univ. of Michigan Press, 2008), 123.

${ }^{28}$ Cf. Gregory Nagy, The Best of the Achaeans. Concepts of the Hero in Archaic Poetry (Baltimore: Johns Hopkins Univ. Press, 1979), 101.

${ }^{29}$ Arthur Schopenhauer, "Die Welt als Wille und Vorstellung I," in Werke in fünf Bänden, ed. Ludger Lütkehaus (Zürich: Haffmanns, 1988 [1819/44]), 688.

${ }^{30}$ See, for example, Ill. 2.484-93; Heraclitus DK 22 B 55, Thales ap. Stobaeus, Florilegium 3.12.14. Cf. Giuseppe Nenci, "Il motivo dell'autopsia nella storiografia greca," $\underline{\operatorname{SCO}} 3$ (1953), 14-46: 17-29.

${ }^{31}$ Cf. Graham Zanker, “Enargeia in the Ancient Criticism of Poetry,” RhM 124 (1981), 297-311: 30910; Alessandra Manieri, L’immagine poetica nella teoria degli antichi: phantasia ed enargeia (Pisa: Istituti Editoriali e Poligrafici Internazionali, 1998), 106; 123 with n. 404.

${ }^{32}$ Quotation from Anonymus Seguerianus, The Art of Political Speech, ed. Mervin R. Dilts (Leiden: Brill, 1997), 96.

${ }^{33}$ George B Walsh, The Varieties of Enchantment. Early Greek Views of the Nature and Function of Poetry (Chapel Hill: Univ. of North Carolina Press, 1984), 5.

${ }^{34}$ The picture becomes even more complex if we follow up Halliwell's observation that Odysseus, after crying after the first song, nonetheless requests another song about himself (Between Ecstasy and Truth, 79-83). There is 'the strong if mysterious impression that Odysseus wants to repeat the experience of the first song' (82). It seems that Odysseus, while obviously not enjoying the recital, nonetheless gets something out of it.

${ }^{35}$ Plut. Quaest. conv. 614c; Himer. Ecl. Or. 16.2-11.

${ }^{36}$ For a more detailed reading of the scene along these lines, see Peponi, Frontiers of Pleasure, $38-44$. 
${ }^{37}$ Segal, Singers, Heroes, and Gods in the Odyssey, 103.

${ }^{38}$ Cf. Pietro Pucci, “The Song of the Sirens,” Arethusa 12 (1979), 121-32; Pietro Pucci, Odysseus

Polutropos: Intertextual Readings in the Odyssey and the Iliad (Ithaca: Cornell Univ. Press, 1987), 209-

13 on the Iliadic character of the Sirens' song; on the lyric overtones, see Peponi, Frontiers of Pleasure, $76-80$.

${ }^{39}$ Max Horkheimer and Theodor W. Adorno, Dialektik der Aufklärung. Philosophische Fragmente (Frankfurt am Main: Fischer, 1969), 34 (translation by Jephcott).

${ }^{40}$ Jeremy Tanner, The Invention of Art History in Ancient Greece. Religion, Society and Artistic Rationalisation (Cambridge: Cambridge Univ. Press, 2006) is an important reminder that the notion of art changed considerably in the course of antiquity, particularly from the Classical period to the Hellenistic era. The capacity of narrative for immersion, however, is an aspect that looms large throughout antiquity.

${ }^{41}$ Julius Caesar Scaliger, Poetices libri septem, ed. August Buck (Stuttgart: Frommann-Holzboog, 1964 [1561]), 144.

${ }^{42}$ For a survey of Heliodorus' impact on the Early Modern novel, see Gerald N. Sandy, Heliodorus (Boston: Twayne, 1982), 95-124.

${ }^{43}$ See Nicolas John Lowe, The Classical Plot and the Invention of Western Narrative (Cambridge: Cambridge Univ. Press, 2000), 249-58 on the Ethiopica's narrative economy (quotation from 258).

${ }^{44}$ John J. Winkler, "The Mendacity of Kalasiris and the Narrative Strategy of Heliodorus' Aithiopika," in Oxford Readings in the Greek Novel, ed. Simon Swain (Oxford: Oxford Univ. Press, 1999), 286350: 336.

${ }^{45}$ John R. Morgan, "Reader and Audiences in the Aithiopika of Heliodorus," in Groningen Colloquia on the Novel IV, ed. Heinz Hofmann and Maike Zimmermann (Groningen: Egbert Forsten, 1991), 85103: 99; cf. Shadi Bartsch, Decoding the Ancient Novel: The Reader and the Role of Description in

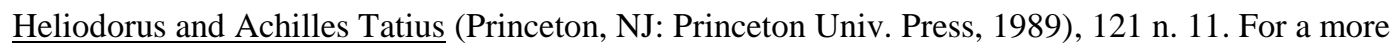
nuanced assessment, see Tim Whitmarsh, Narrative and Identity in the Ancient Greek Novel: Returning Romance (Cambridge: Cambridge Univ. Press, 2011), 172-76.

\footnotetext{
${ }^{46}$ On this passage, see Bartsch, Decoding the Ancient Novel, 120-22; Philip Hardie, "A reading of
} 
Helidorus, Aithiopika 3.4.1-5.2," in Studies in Heliodorus, ed. Richard Hunter (Cambridge: Cambridge Philological Society, 1998), 19-39: 26-33; Richard L. Hunter, “The Aithiopika of Heliodorus: Beyond Interpretation?," in Studies in Heliodorus, ed. Richard L. Hunter (Cambridge: Cambridge 1998), 40-59: 55-56; Whitmarsh, Narrative and Identity in the Ancient Greek Novel, 172-76.

${ }^{47}$ Hardie, “A reading of Helidorus, Aithiopika 3.4.1-5.2,” 27.

${ }^{48}$ Cnemon takes this use up in the following section 3.4.10.

${ }^{49}$ Cf. Hardie, “A reading of Helidorus, Aithiopika 3.4.1-5.2,” 26.

${ }^{50}$ John R. Morgan, "History, Romance, and Realism in the Aithiopika of Heliodorus," ClAnt 1 (1982), 221-65: 260 .

${ }^{51}$ See also Felski, Uses of Literature, 73-74, who points out that 'absorption and artifice are often coterminous rather than mutually exclusive'.

${ }^{52}$ Arthur Coleman Danto, After the End of Art: Contemporary Art and the Pale of History (Princeton: Princeton Univ. Press, 1997), 25.

${ }^{53}$ Martin Seel, “Art as Appearance. Two Comments on Arthur C. Dantos After the End of Art,” $\underline{\text { H\&T }}$ 37 (1998), 102-14: 106. See also Martin Seel, Ästhetik des Erscheinens (Munich: Hanser, 2000), 19297.

${ }^{54}$ Paul Oskar Kristeller, "The Modern System of the Arts," in Renaissance Thought and the Arts. Collected Essays, ed. Paul Oskar Kristeller (Princeton: Princeton Univ. Press, 1990), 163-227: 174. For the continuing influence of Kristeller's argument, see Larry Shiner, The Invention of Art: A Cultural History (Chicago: Chicago Univ. Press, 2001) and the titles listed by Michael Squire, "Introduction: The Art of Art History in Greco-Roman Antiquity," Arethusa 43 (2010), 133-63: 140 n. 23.

${ }^{55}$ Besides Jim I. Porter, “Is Art Modern? Kristeller's Modern System of the Arts reconsidered,” British Journal of Aesthetics 49 (2009a), 1-24 and Jim I. Porter, "Reply to Shiner,” British Journal of Aesthetics 49 (2009b), 171-78 (the latter a response to Larry Shiner, "Continuity and Discontinuity in the Concept of Art," British Journal of Aesthetics 49 (2009), 159-69), see also Halliwell, Aesthetics of Mimesis, 7-9; Charles Martindale, Latin Poetry and the Judgement of Taste. An Essay in Aesthetics (Oxford: Oxford Univ. Press, 2005), 31-3. For various positions on the notion of ancient art and aesthetics, see the contributions to Michael Squire and Verity Platt, ed., The Art of Art History in 
Greco-Roman Antiquity (Baltimore: Johns Hopkins Univ. Press (Arethusa), 2010).

${ }^{56}$ See, for example, Richard L. Gordon, "The Real and the Imaginary. Production and Religion in the Graeco-Roman World," Art History 2 (1979), 5-34; Deborah Tarn Steiner, Images in Mind: Statues in Archaic and Classical Greek Literature and Thought (Princeton and Oxford: Princeton Univ. Press, 2001), 79-134; Jaś Elsner, Roman Eyes: Visuality and Subjectivity in Art and Text (Princeton:

Princeton Univ. Press, 2007), 1-48; Verity Platt, Facing the Gods: Epiphany and Representation in

Graeco-Roman Art, Literature and Religion (Cambridge: Cambridge Univ. Press, 2011), 77-123.

${ }^{57}$ Elsner, Roman Eyes, 45.

${ }^{58}$ Tanner, The Invention of Art History in Ancient Greece.

${ }^{59}$ Tanner, The Invention of Art History in Ancient Greece, 264-75.

${ }^{60}$ See also Richard T. Neer, The Emergence of the Classical Style in Greek Sculpture (Chicago: Univ. of Chicago Press, 2010a); Richard T. Neer, “Jean-Pierre Vernant and the History of Image,” Arethusa 43 (2010b), 181-95; Porter, The Origins of Aesthetic Thought in Ancient Greece, who, if along different lines, tap into phenomenology to approach ancient aesthetics. For a balanced assessment of the value of phenomenology for an exploration of aesthetic experience in general, see Felski, Uses of Literature, $16-20$.

${ }^{61}$ See, for example, Norman Bryson, Vision and Painting. The Logic of the Gaze (London: Macmillan, 1983), 62 on pictorial seeing: '...recognition is through-written by social codes, and not only in an alleged 'second phase' of apprehension.'

${ }^{62}$ Focusing on the phenomenological aspect of aesthetic experience, my notion of 'as-if' is markedly different from other uses of the term. Hans Vaihinger, Die Philosophie des Als-Ob: System der theoretischen, praktischen und religiösen Fiktionen der Menschheit auf Grund eines idealistischen Positivismus; mit einem Anhang über Kant und Nietzsche (Berlin: Reuther \& Reichard, 1911) deployed the idea of 'as-if' to explain the usefulness of scientific, religious and other models. They do not match reality, but we benefit from behaving as if they did. More recently, Michael Saler, As If. Modern Enchantment and the Literary Prehistory of Virtual Reality (New York and Oxford: Oxford Univ. Press, 2012) uses 'as-if' to explore our relation to the kind of imaginary worlds that started to emerge with Sherlock Holmes at the end of the 19th century. My approach is closer to the concept of 'make-believe' that Kendall L. Walton, Mimesis as Make-Believe: On the Foundations of 
Representational Arts (Cambridge, MA: Harvard Univ. Press, 1990) coined as an anthropological category which describes our engagement with representational arts. However, my notion of 'as-if' is not identical with Walton's 'make-believe'. Let me mention just two points: the idea of 'as-if' does not involve the strange notion of books as 'props' nor does my adoption of Wollheim's notion of 'seeingin' chime with the role of imagination in Walton's concept of pictorial seeing.

${ }^{63}$ Edmund Husserl, "Vorlesungen zur Phänomenologie des inneren Zeitbewußtseins," in Husserliana X, ed. Rudolf Boehm (Den Haag: Martinus Nijhoff, 1966).

${ }^{64}$ Husserl, "Vorlesungen zur Phänomenologie des inneren Zeitbewußtseins,” 29: ‘Das Ton-Jetzt wandelt sich in Ton-Gewesen, das impressionale Bewußtsein geht ständig fließend über in immer neues retentionales Bewußtsein. Dem Fluß entlang oder mit ihm gehend, haben wir eine stetige zum Einsatzpunkt gehörige Reihe von Retentionen.'

${ }^{65}$ Husserl takes pains to offset the reproductive consciousness of memory from primary retention ("Vorlesungen zur Phänomenologie des inneren Zeitbewußtseins," §§19-22) as well as from phantasy which does not relate to a past impression ("Vorlesungen zur Phänomenologie des inneren Zeitbewußtseins,” §23).

${ }^{66}$ Husserl, "Vorlesungen zur Phänomenologie des inneren Zeitbewußtseins,” §24: 52-53.

${ }^{67}$ Husserl, "Vorlesungen zur Phänomenologie des inneren Zeitbewußtseins," §26: 55-57.

${ }^{68}$ Husserl, "Vorlesungen zur Phänomenologie des inneren Zeitbewußtseins,” §24.

${ }^{69}$ Husserl, "Vorlesungen zur Phänomenologie des inneren Zeitbewußtseins," §26.

${ }^{70}$ Cf. Jonas Grethlein, “The Narrative Reconfiguration of Time beyond Ricœur,” Poetics Today 31 (2010), 313-29.

${ }^{71}$ On this point, see, from different perspectives, Walton, Mimesis as Make-Believe introducing the concept of 'make-believe'; Jean-Marie Schaeffer, Pourquoi la fiction? (Paris: Seuil, 1999) deploying the notion of fiction.

${ }^{72}$ Neer, The Emergence of the Classical Style in Greek Sculpture, 14-9. See also Neer, "Jean-Pierre Vernant and the History of Image" for a slightly different presentation of the argument, this time including a comparison of the historical semantics of homosexuality and images. For Vernant's argument, see especially Jean-Pierre Vernant, Figures, idoles, masques (Paris: Julliard, 1990), 17-82. 
${ }^{73}$ Neer, The Emergence of the Classical Style in Greek Sculpture, 18.

${ }^{74}$ Neer, The Emergence of the Classical Style in Greek Sculpture, $17-18$.

${ }^{75}$ Neer, The Emergence of the Classical Style in Greek Sculpture, 18.

${ }^{76}$ Richard Wollheim, "Seeing-As, Seeing-In, and Pictoral Representation," in Art and its Objects, ed. Richard Wollheim (Cambridge: Cambridge Univ. Press, ${ }^{2} 1980$ ), 205-26: 213-14; Richard Wollheim, Painting as an Art (London: Thames and Hudson, 1987), 46 n. 6.

${ }^{77}$ Wollheim, "Seeing-As, Seeing-In, and Pictoral Representation," 215-16.

${ }^{78}$ Wollheim, "Seeing-As, Seeing-In, and Pictoral Representation,” 216.

${ }^{79}$ Wollheim, Painting as an Art, 46; cf. Richard Wollheim, "On Pictorial Representation," in Richard Wollheim on the Art of Painting. Art as Representation and Expression, ed. Rob van Gerwen (Cambridge: Cambridge Univ. Press, 2001), 20.

${ }^{80}$ Wollheim, Painting as an Art, 73; cf. Wollheim, “On Pictorial Representation,” 20.

${ }^{81}$ Besides the systematic critique of Malcolm Budd, "On Looking at a Picture," in Psychoanalysis, Mind and Art. Perspectives on Richard Wollheim, ed. James Hopkins and Antony Savile (Oxford: Blackwell, 1992), 259-80, see also Flint Schier, Deeper Into Pictures: An Essay on Pictorial Representation (Cambridge: Cambridge Univ. Press, 1986), 199-205; Kendall L. Walton, "Seeing-In and Seeing Fictionally," in Psychoanalysis, Mind and Art: Perspectives on Richard Wollheim, ed. James Hopkins and Anthony Savile (Oxford: Blackwell, 1992), 281-91; Dominic Lopes, Understanding Pictures (Oxford: Clarendon Press, 1996), 43-51; Robert Hopkins, Picture, Image and Experience: A Philosophical Inquiry (Cambridge: Cambridge Univ. Press, 1998), 18-20; the contributions to Rob van Gerwen, ed., Richard Wollheim on the Art of Painting. Art as Representation and Expression (Cambridge: Cambridge Univ. Press, 2001).

${ }^{82} \mathrm{Cf}$. Wollheim, Painting as an Art, 46. For a critique of this limit of 'seeing-in', see, e.g., Walton, "Seeing-In and Seeing Fictionally"; Lopes, Understanding Pictures, 44; Hopkins, Picture, Image and Experience, 17. To fill the gap, Malcolm Budd, "How Pictures Look," in Virtue and Taste. Essays on Politics, Ethics and Aesthetics. In Memory of Flint Schier, ed. Dudley Knowles and John Skorupski (Oxford: Blackwell, 1993), 154-75; Christopher Peacocke, "Depiction,” The Philosophical Review 96 (1987), 383-410 have resuscitated the idea of resemblance that had lost much credit after Goodman's invective against it. Other scholars such as Schier, Deeper Into Pictures; Lopes, Understanding Pictures 
elaborate on the recognitional aspect of seeing pictures. Walton, Mimesis as Make-Believe presses the idea of imagination and speaks of 'make-believe'. See Wollheim, "On Pictorial Representation" for a critique of some of these approaches.

${ }^{83}$ Alfred Gell, Art and Agency. An Anthropological Theory (Oxford: Clarendon Press, 1998), 97.

${ }^{84}$ Gell, Art and Agency, 116-21.

${ }^{85}$ Gell, Art and Agency, 116.

${ }^{86}$ The notion of 'as-if' could also developed for other media of artistic representation. See, for example, the reflection on sculpture in Neer, The Emergence of the Classical Style in Greek Sculpture, 105.

${ }^{87}$ In the modern era, too, art serves social functions. See, for example, Pierre Bourdieu, La distinction. Critique sociale du jugement (Paris: Édtions de Minuit, 1979), who coins the term of 'cultural capital'; and Terry Eagleton, The Ideology of the Aesthetic (Oxford: Blackwell, 1990) on 'the ideology of the aesthetic'.

${ }^{88}$ Hans Jonas, "Homo Pictor: Von der Freiheit des Bildens," in Was ist ein Bild?, ed. Gottfried Boehm (Munich: Fink, 1994), 105-24: 111.

${ }^{89}$ Hans-Georg Gadamer, Wahrheit und Methode. Grundzüge einer philosophischen Hermeneutik (Tübingen: Mohr, $\left.{ }^{5} 1986\right), 92-93 ; 139-40$. 